
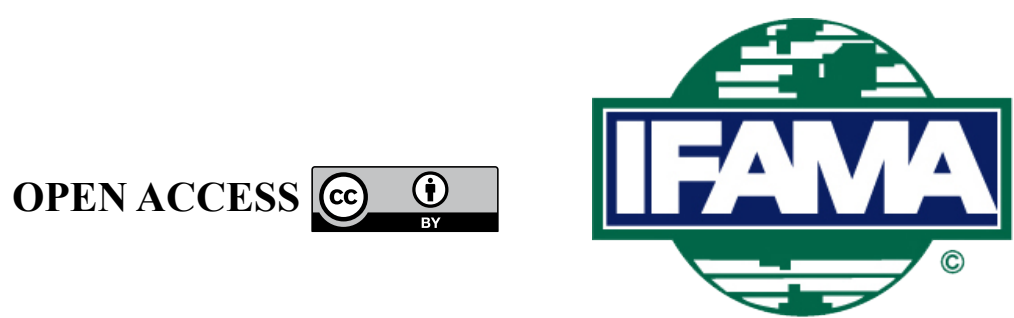

International Food and Agribusiness Management Review

Volume 25, Issue 3, 2022; DOI: 10.22434/IFAMR2020.0030

Received: 20 February 2020 / Accepted: 18 November 2021

\title{
Assessing the financial health of agricultural enterprises incorporating the spatial dimension
}

\section{RESEARCH ARTICLE}

\author{
Roman Vavrek ${ }^{\mathrm{a}}$, Ivana Kravčáková Vozárová ${ }^{\circledR b}$, Rastislav Kotuličc ${ }^{\mathrm{c}}$ Peter Adamišin ${ }^{\mathrm{c}}$, \\ Mariana Dubravskáb and Viera Ivankovád \\ ${ }^{a} P h D, V \check{S} B$ - Technical University of Ostrava, Faculty of Economics, \\ Sokolská tř́da 33, 70200 Ostrava, Czech Republic \\ ${ }^{b}$ Ing. PhD, ${ }^{c}$ Associate Professor, University of Presov, Faculty of Management \\ and Business, Konštantínova 16, Prešov 080 01, Slovak Republic \\ ${ }^{d}$ Manager PhD, Institute of Earth Resources, Faculty of Mining, Ecology, Process Control and \\ Geotechnologies, Technical University of Košice, Letná 9, Košice 042 00, Slovak Republic
}

\begin{abstract}
In practice, different methods are used to assess the financial health of a company, and the fact that models use the various indicators complicates the comparison of their results. The aim of this paper was to identify the financial health of agricultural enterprises operating in the Slovak Republic using three selected creditworthy models (the Altman model, Taffler model and Bonity Index). It was concluded that the differences in the evaluations of agricultural enterprises using individual creditworthy models were significant. The analysis was supplemented by the spatial distribution of the enterprises at the level of individual regions of the Slovak Republic. It was confirmed that the spatial differences in the evaluations of agricultural enterprises using individual creditworthy models were not statistically significant and were therefore random. The proposal of own assessment of regions is based on the combination of the obtained results and their spatial distribution. We assume that such comprehensive assessment over a longer period of time may be an appropriate tool for assessing the financial health of agricultural enterprises, thus contribute to the early identification of potential risks and the long-term economic sustainability. This study can be the contribution in helping to design policies or effective solve the important challenges of agricultural enterprises to the path of sustainable development of the regions and to environmental management.
\end{abstract}

Keywords: financial health, creditworthy models, agricultural enterprises, spatial dimension JEL code: Q10

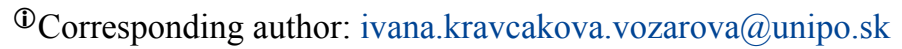




\section{Introduction}

In the current stage of development of the world economy, attention is being focused on the financial condition and possible future directions of entities operating in the market economy. The decisive factors affecting the financial health of enterprises are also currently an issue of importance in agriculture, which is the primary sector of the national economy of the Slovak Republic. It is therefore important for farmers to understand the underlying factors affecting their prosperity, success and performance in order to achieve sustainable long-term business development. Rising globalization in the world, openness, and integration reinforce the importance of these factors. In connection with long-term growth, it is necessary to make an objective assessment of the current position of a company, its financial capabilities and its ability compared to its own set objectives and competing enterprises in the sector.

Agricultural companies have recently been characterized by the stagnation of their production efficiency, i.e. the stagnation of the total agricultural production of the Slovak Republic. The stagnation of gross agricultural output was due to a fall in value due to prices (mainly raw cow's milk and slaughter pigs) and an increase in the production of almost all major commodities of plant production (except for barley, legumes and fruit) and livestock production (excluding cows' milk). The business environment is currently affected mainly by trade risks arising from the volatility of agricultural commodity markets, the European Union support system within the common agricultural policy and internal factors, in particular the impact of legislation, economic and financial instruments (national aid, loans, insurance, taxes and levies into funds, etc.), and management decisions and austerity measures within enterprises. A national or regional community's interest in agricultural development processes, which are induced by agricultural policy projects or measures, requires a change in scale and, at the same time, the use of specific economic tools (Cochet, 2015). These conditions increase the importance of analyzing and evaluating the financial health of companies and their subsequent responses through concrete measures that take into account the financial health and success of the business.

Financial health or performance can be considered from different perspectives: according to Richard et al. (2009), organizational performance comprises three specific areas of business performance: (1) financial performance (profits, return on assets, return on investment, etc.); (2) market performance (sales, market share, etc.); and (3) return on shareholders (total return on shareholders, economic value added, etc.). According to Maciková et al. (2018), the financial health has been one of the leading topics of the financial management of the Slovak companies since the beginning of the millennium. Under the pressure of the business environment, the environmental aspects of sustainability were supplemented by the economic and social dimensions in recent years. The indicators used to evaluate farm financial performance in any one year are different from those used to assess the financial health of a business (Herdt and Lynam, 1992; Shadbolt et al., 1997). There are several authors who have examined the financial health of agricultural companies, including Adamišin et al. (2017); Dvořák (2007); Henning and Jordaan (2016); Kravčáková Vozárová et al. (2016), Lopez-Valeiras et al. (2016); Majewski (2013); Martínez-Victoria et al. (2018); Sjauw-Koen-Fa et al. (2016); or Vavrek et al. $(2021 \mathrm{a}, \mathrm{b})$. Despite these research, there is still a scarcity of studies that engage in designing a systematic and comprehensive model for measuring the financial health of the agricultural companies.

One of the most significant problems in agricultural development is finance (Ozalp, 2019). Pokharel et al. (2019) have stated that financially nonstressed agricultural cooperatives have a higher rate of return on equity and a higher rate of return on assets, indicating their better financial health. Financial stress is linked to financing decisions, and therefore it is necessary to focus on the financial aspects of agricultural firms. Yaremko et al. (2018) have also included a financial component among the components of the economic security of agricultural firms. According to Martínez-Victoria et al. (2018), the firms that are quicker to react in terms of adjusting their financial magnitudes to the sectorial average values have more internal incentives to readjust their financial magnitudes. These firms will be more dependent on external market characteristics. This finding is useful for understanding and predicting firms' financial behavior when financial management policies are designed to promote agri-food firms' performance. The agricultural companies are dynamic organisations with long-term transformation processes. These were induced by the signals from the external 
environment or caused by the decisions of farmers resulting from the changes of internal conditions. The agricultural policy offers tools and financial resources supporting the desired transformation orientations and thus improving the level of their financial health (Majewski, 2013). Henning and Jordaan (2016) argued that the financial health and the ability to raise financial capital is an essential factor in farming production. Without access to credit, most farmers would be unable to reap the maximum returns from the natural resources available to them. According to Zorn et al. (2018), given sectoral specificities such as production tied to natural processes, seasonal aspects of production or the dominance of family farms, it is necessary to specifically analyze the economic indicators of farms. Rábek and Tóth (2013) evaluated the development of the profitability of Slovak agriculture based on individual data from the balance sheet and profit-and-loss statements in the period 2004-2011. They found high volatility for all the analyzed profitability indicators, namely return on investment, return on equity and return on sales. They also evaluated agriculture as a lowprofit sector.

A financial health assessment using predictive bankruptcy and credibility models is a common method in any business field or geographical environment (Alaminos et al., 2016; Bellovary et al., 2007; Gavurová et al., 2017; Valášková et al., 2018), including in agriculture. Nývltová (2016) has evaluated agricultural enterprise models in the Czech Republic, and the IN05 model turned out to be the most reliable model in determining the financial problems of an enterprise. Valášková et al. (2017) compared creditworthy models adapted to the conditions of Slovak agricultural companies. Although the models were developed for the conditions of Slovak agriculture, only one model - the Gurčík model - achieved an acceptable level of classification and predictive ability (almost 60\%) (Gurčík, 2002). The other models included in the comparison - the Chrastinova model (Chrastinová, 1998) and the universally acknowledged Altman model - did not reach the required lower limit (Altman, 1968). Bod'a and Úradníček (2019) have admitted that the use of 'older' models brings with it some level of trustworthiness when using financial distress as an indicator of the financial health of Slovak agricultural enterprises, but the Gurčík model can be reliable. Harumová and Janisová (2014) have stated that these models, especially the Altman model, need to be updated in order to be relevant to different business environments and conditions. Many other authors have dealt with the financial health of agricultural entities using predictive models, and the results have varied (Karas et al., 2017; Kopta, 2009). This unclear view confirmed the need to develop a comprehensive model predicting the financial health of Slovak companies that takes into account the current scientific knowledge and applied statistical methods in predicting the financial situation. Bod'a and Úradniček (2019) have identified three key indicators in predicting financial distress: (1) gross return on revenue; (2) the debt ratio; and (3) days payable outstanding. Gurčík et al. (2015) examined the impact of the debt burden on the prosperity of agricultural companies, with prosperity expressed as return on assets (ROA). The level of debt of the agricultural holdings in the analyzed region of the Slovak Republic increased their return on assets.

Mateos-Ronco and Guzman-Asuncion (2018) have shown positive relationships between the level of debt of cooperatives and other factors such as long-term investment, liquidity, and the cooperative's size in terms of turnover per member. Relationships between debt size and cooperatives indicate that cooperatives with higher turnover per member tend to borrow more. This indicates that they are more dynamic in terms of business activity and tend to take greater financial risks for development and internationalization. Finally, the results obtained for the relationship between performance and debt level are not critical, because although there is evidence of a significant relationship between them - which is consistent with previous research theories - they cannot be generalized. A similar study was conducted by Ali (2018), which, through analysis of variance, indicated significant differences in enterprise performance in small, medium and large farms in terms of input and output ratios.

An overview of the use of predictive models can be found in studies by Boratynska (2016), Zvarikova et al. (2017) or Prusak (2018). Bondareva (2013) states that the financial health of an enterprise depends on its ability to fulfill the main purpose of its existence under market economy conditions, i.e. the ability to achieve the levels of capital appreciation demanded by investors with regard to the level of risk. Oreský (2017) also argues that a financially healthy company is not only profitable, but also liquid. In this respect, 
the long-term ability to meet its obligations is important. The opinion of many authors is that the inherent prerequisite of an enterprise having a favorable financial condition is the financial performance, that is, the ability to generate the added value of the business. Thus, the financial performance is reflected in the profitability of the enterprise. One of the methods of financial analysis is a multidimensional discriminatory analysis, which includes bankruptcy models that classify businesses as prosperous or non-prosperous on the basis of multiple indicators that are not overlapping. These include Altman's Z-score, the Springate model, Fulmer model, Taffler model, and the Bonity index, which are still considered to be relevant tools (Kabát et al., 2013; Mandru, 2010). Their relevance is also documented by the several modifications of, e.g. the Altman model (Altman, 2000, 2002; Altman et al., 1977).

According to Altman (2018), we can now reflect on a large number of applications and can divide them into two main categories: (1) those from analysts external to the firms in question; and (2) those by managers within the entity itself (Table 1).

The results of Klepáč and Hampel (2017) show that with an increasing distance to bankruptcy, there is a decreasing average accuracy of financial distress prediction and there is a greater difference between the active and distressed agriculture companies in terms of liquidity, rentability and debt ratios. Dinterman et al. (2017) also indicate a dynamic relationship between farm bankruptcies and the value of agricultural land, where current year values are negatively related but previous year land values are positively related to bankruptcies. Further evaluation using selected bankruptcy models, not only for the Slovak Republic and the Czech Republic, has been carried out by several authors, including Karas and Rezňáková (2014), Rybárová et al. (2016), Sapozhnikova et al. (2017), Zhminko and Zhminko (2014), and Novotná and Svoboda (2014).

This paper clarifies the issue of the financial health of enterprises operating in the territory of the Slovak Republic using a total sample of 469 subjects and analyzes them on the basis of the obtained results. The purpose of the study was to fill the gap in the field of researching the issue in the conditions of Slovak agricultural enterprises and to bring a broader view of the use of discriminatory analysis in the assessment of financial health. A significant contribution was the comparison of the evaluation of individual models, which reached different values across the entire monitored period. The use of several methods has contributed to the complexity of evaluation, which can be beneficial for agricultural entities in the processes of optimal managerial decision-making in order to optimize business risks, which are extremely specific in the agricultural field. The presented study and the results resulting from it make it possible to expand the relationship between current scientific knowledge about the prediction of the financial situation of agricultural companies and empirical knowledge from practice.

Table 1. Use of creditworthy models (Altman, 2002).

\begin{tabular}{|c|c|}
\hline External (to the firm) analytics & Internal (to the firm) and research analytics \\
\hline Lenders (e.g. pricing, basel capital allocation) & $\begin{array}{l}\text { To file or not (e.g. General Motors) comparative risk } \\
\text { profiles over time }\end{array}$ \\
\hline Bond investors (e.g. quality junk portfolio) & Industrial sector assessment (e.g. energy) \\
\hline Long/short investment strategy on stocks (e.g. baskets & Sovereign default risk assessment \\
\hline of strong balance sheet companies \& indexes) e.g. & Purchasers, suppliers assessment \\
\hline STOXX, Goldman, Sachs, Morgan Stanley & Accounts receivables management \\
\hline Security analysts \& Rating agencies & Chapter 22 assessment \\
\hline Regulators and government agencies & Researchers - scholarly studies \\
\hline Auditors (audit risk, going concern model) & Managers - managing a financial turnaround \\
\hline \multicolumn{2}{|l|}{ Advisors (e.g. assessing client' health) } \\
\hline M\&A (e.g. bottom fishing) & \\
\hline
\end{tabular}




\section{Materials and methods}

In practice, various methods and models are used to assess the financial health of a company, whose predicative ability and heterogeneous composition of indicators make it difficult to compare their results, as is shown above. The aim of this paper was to identify the financial health of 469 agricultural enterprises operating in the Slovak Republic using three creditworthy models (the 1968 Altman model, the Taffler model, and the Bonity index). We sought to answer the following three research questions:

RQ1: Is the assessment of the financial health of enterprises dependent on the used creditworthy model?

RQ2: Does the legal form affect the evaluating the financial health of enterprises using individual creditworthy models?

RQ3: Is the financial health of agricultural enterprises spatially independent?

The basic prerequisite of the first of the research questions (RQ1) is a heterogeneous structure of the monitored indicators. This means that the identification of potential financial problems, which is the intention of every creditworthy model, is based on an assessment of other facts. In the case of the second research question (RQ2), we assumed that the state has influence in terms of passing legal regulations allowing enterprises to operate as an agricultural cooperative or as an enterprise in another legal form. The third research question (RQ3) focused on an interpretation of the results from a spatial perspective (at the level of the NUTS III administrative regions - Nomenclature of Territorial Units for Statistics). For each of the research questions, the research hypotheses were set as follows:

H1: We assumed that there is a statistically significant difference in the overall assessment of agricultural enterprises using different creditworthy models (the 1968 Altman model, the Taffler model, and the Bonity index).

H2: We assumed that there is a statistically significant difference in the overall assessment of agricultural enterprises with different legal structures (agricultural cooperatives or other forms of business).

H3: We assumed that overall evaluations of agricultural enterprises using individual creditworthy models (the 1968 Altman model, the Taffler model, and the Bonity index) are spatially independent in terms of higher territorial units (the NUTS III level).

The data for the analysis came from agricultural companies (balance sheets, profit and loss statements, etc.) and were provided by the Ministry of Agriculture and Rural Development of the Slovak Republic in the form of information sheets on anonymized agricultural enterprises. The total sample included 2,509 subjects - both 'legal' and 'natural' persons - with up to 19 or over 20 employees in the period following the accession of Slovakia to the European Union (2004-2016). The information sheets captured economic data for agricultural holdings that managed $81.3 \%$ of the utilized agricultural area of Slovakia $(1,930,570$ ha). Of this set of enterprises, 469 enterprises were identified for use in our study through economic software for financial planning and managerial economy (the SOFINA standard (Király et al., 2015)). Only these enterprises had continuous financial data for the period under review and had flawless, balanced control over their financial statements.

To carry out the research and answer the research questions, 469 agricultural subjects were evaluated for a period of 13 years, from 2004 to 2016. Of these 469 agricultural subjects, there were 278 agricultural cooperatives and 191 enterprises of another legal form. In the analysis, NUTS III nomenclature was used for the administrative classification of regions, where BSK meant the Bratislava region, TSK the Trnava region, TTSK the Trenčín region, NSK the Nitra region, ZSK the Žilina region, BBSK the Banská Bystrica region, PSK the Prešov region, and KSK the Košice region (Figure 1). 


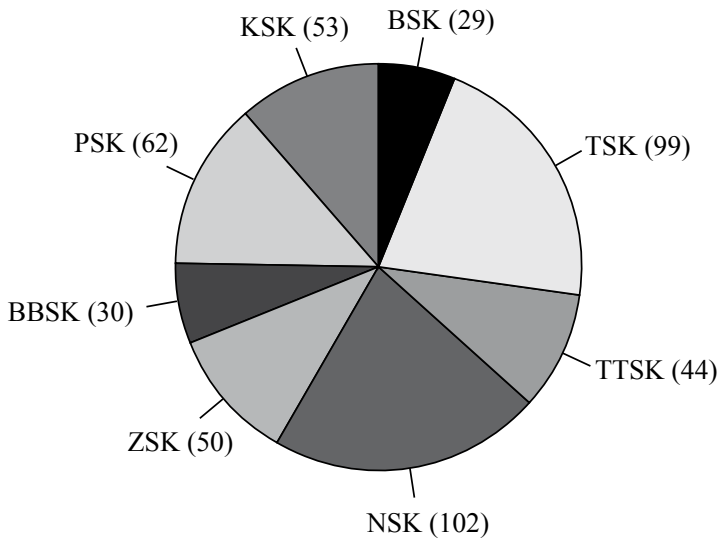

Figure 1. Research sample according to NUTS III cassification. BBSK = Banská Bystrica region; BSK = Bratislava region; $\mathrm{KSK}=$ Košice region; $\mathrm{NSK}=$ Nitra region; $\mathrm{PSK}=$ Prešov region; $\mathrm{TSK}=$ Trnava region; TTSK $=$ Trenčín region; ZSK = Žilina region.

By evaluating such a long period, we sought to identify not only differences in the analyzed sample, but also trends. In order to compare the obtained results, absolute values were converted into intervals, which were determined by the authors and which are described in Table 2.

The evaluation of the results was complemented by the use of several mathematical/statistical methods (see Section 3.1). All calculations and analyses were performed in MS Excel (Microsoft, Redmond, WA, USA), Statistica 13.4 (TIBCO Software Inc, Palo Alto, CA, USA), and Statgraphics XVIII (Statgraphics Technologies, Inc., The Plains, VA, USA).

\subsection{Used mathematical-statistical methods}

The results obtained from the realized analyses and evaluated agricultural enterprises using of the creditworthy models (Altman model, Taffler model and Bonity index) were described by the selected moment characteristics (Table 3).

The mathematical-statistical models used include: First, a Kruskal-Wallis test was used, where the difference in the mean value of the total annual results of individual creditworthy models was observed:

$$
Q=\frac{12}{n(n-1)} \sum_{i=1}^{I} \frac{T_{i}^{2}}{n_{i}}-3(n+1),
$$

where $n$ is the total number of observations, $n_{i}$ is the number of observations in the $\mathrm{i}$-th group, $T_{i}^{2}$ is the total sum of ranks in the i-th group.

Table 2. Interpretations of the evaluation of individual creditworthy models.

\begin{tabular}{llll}
\hline Model & Interval & Evaluation & Interpretation \\
\hline Altman model (Z) & $Z \epsilon<2.99 ; \infty)$ & index A & healthy enterprise \\
& $Z \epsilon<1.81 ; 2.99)$ & index B & grey zone \\
& $Z \epsilon(-\infty ; 1.81)$ & index C & assumption of problems in the future \\
Taffler model (T) & $T \epsilon<0.3 ; \infty)$ & index A & healthy enterprise \\
& $T \epsilon<0.2 ; 0.3)$ & index B & grey zone \\
& $T \epsilon<-\infty ; 0.2)$ & index C & assumption of problems in the future \\
Bonity index (IB) & $I B \epsilon<3 ; \infty$ & index A & healthy enterprise \\
& $I B \epsilon<0 ; 3)$ & index B & grey zone \\
& $I B \epsilon<-\infty ; 0)$ & index C & assumption of problems in the future \\
\hline
\end{tabular}


Table 3. Characteriscs of variables used (for the whole monitored period 2004-2016).

\begin{tabular}{|c|c|c|c|c|c|c|c|}
\hline Name of variable & Type of variable & $\bar{x}$ & $\tilde{\boldsymbol{x}}$ & $s_{x}$ & $\mathbf{R}$ & $\mathbf{Q}_{1}$ & $\mathbf{Q}_{3}$ \\
\hline \multicolumn{8}{|c|}{ Type of agricultural subject qualitative, discrete, binomial } \\
\hline Region & $\begin{array}{l}\text { qualitative, discrete, } \\
\text { multinomial, nominal }\end{array}$ & & & & & & \\
\hline Altman model results $(Z)$ & $\begin{array}{l}\text { quantitative, continuous, } \\
\text { multinomial, cardinal }\end{array}$ & 2.78 & 1.86 & 25.53 & $1,979.81$ & 0.96 & 3.13 \\
\hline Taffler model results $(\mathrm{T})$ & $\begin{array}{l}\text { quantitative, continuous, } \\
\text { multinomial, cardinal }\end{array}$ & 0.45 & 0.30 & 6.02 & 585.54 & 0.18 & 0.47 \\
\hline Bonity index results (IB) & $\begin{array}{l}\text { quantitative, continuous, } \\
\text { multinomial, cardinal }\end{array}$ & 1.27 & 1.08 & 8.98 & 732.72 & 0.43 & 2.06 \\
\hline
\end{tabular}

A Levene test was also used: we observed the differences in the dispersion of the obtained results according to the legal form of the agricultural enterprises:

$$
L E=\frac{(N-k)}{(k-1)} \frac{\sum_{i=1}^{k} N_{i}\left(Z_{i}-Z_{. .}\right)^{2}}{\sum_{i=1}^{k} \sum_{j=1}^{N_{i}}\left(Z_{i j}-Z_{i .}\right)^{2}},
$$

where $k$ is the number of values in the monitored variable category, $N$ is the total number of observations, $N_{i}$ is the number of observations in the i-th group, $Y_{i j}$ is the measured value of the j-th unit of the i-th group, $\bar{Y}_{l}$ is the average value of the $\mathrm{i}$-th group, $\tilde{Y}_{i}$ is the median of the $\mathrm{i}$-th group, $Z_{\text {.. }}$ is the average of the groups (Zij), and $Z_{i}$ is the average of $\mathrm{Zij}$ for the $\mathrm{i}$-th group.

We also used a Kolmogorov-Smirnov test, through which we tested the conformity of the distribution functions to the results obtained in terms of agricultural enterprises according to their legal form:

$$
\begin{aligned}
K S= & \sup \left|F_{1, n_{1}}(x)-F_{2, n_{2}}(x)\right|, \\
& -\infty<x<\infty
\end{aligned}
$$

where $F_{1, n_{1}}(x)$ is an empirical distribution function of the first selection, $F_{2, n_{2}}(x)$ i is an empirical distribution function of the second selection.

In addition, we used a Mann-Whitney test, which tested the differences in the mean values of the results obtained in terms of agricultural enterprises according to legal form:

$$
U^{\prime}=n_{y} n_{x} \frac{n_{y}\left(n_{y}+1\right)}{2}-R_{y}, U=n_{y} n_{x}-U^{\prime},
$$

where $n_{x}$ is the number of observations or the range of the $\mathrm{x}$-th file, $n_{y}$ is the number of observations with respect to the of the $\mathrm{y}$-th file, $R_{y}$ - the sum of the ranks of the $\mathrm{y}$-th file, and $\mathrm{U}, \mathrm{U}^{\prime}$ are test statistics.

Finally, we used a Moran index, through which we tested the spatial relationships of the results obtained at the NUTS III level:

$$
I_{i}(d)=\frac{x_{i}-\bar{x}}{\frac{\sum_{j=1 ; i \neq 1}^{n} w_{i j}(d)}{n-1}-\bar{x}^{2}} \sum_{j=1 ; i \neq 1}^{n} w_{i j}(d)\left(x_{j}-\bar{x}\right)
$$

where $d$ is the critical distance, $n$ is the number of spatial units, $x_{i}$ is the value of the examined phenomenon in the spatial unit i, $\bar{x}$ is the average value of the examined phenomenon, and $w_{i j}(d)$ is the distance weight. 


\section{Results and discussion}

The results of the research are presented here in a total of four parts. In the first three sections $(3.1,3.2$, and 3.3), attention is paid to evaluating the results separately for each of the creditworthy models used. We point out the differences and trends identified during the 13-year reporting period using the set of mathematical and statistical methods described above. In the last subchapter (3.4), these results are compared so as to answer the research questions and evaluate the research hypotheses.

\subsection{Evaluation of entities based on the Altman model}

Throughout the reporting period, the agricultural enterprises showed the same, positive skewness $\left(\hat{x}_{A L T}<\tilde{x}_{A L T}\right)$, indicating that a large number of entities had a bad assessment. The median annual value for the assessment was close (with the exception of 2009) to the threshold for the A rating, i.e. 2.99, but never exceeded it. The highest value was in 2011, when $\tilde{x}_{A L T 2011}=2.94$. Looking at the average annual values, it can be noted that in 6 of the 13 years analyzed, this rating was less than 1.81, and therefore the agricultural enterprises were exposed to a risk of financial problems.

From these moment characteristics (Figure 2), it was not possible to extrapolate long-term positive or negative trends. The worst-ranked companies achieved negative values every year. In terms of the bestranked companies, there were extreme values that were several times higher than the ratings of other entities. This was supported by the homoskedasticity of the annual results ( $\mathrm{LE}=1.6407 ; P=0.0735)$. In the medium term, however, we could observe a decline in the level of financial health, as was indicated by the post-2009 results, which were significantly worse than in the previous years $(\mathrm{Q}=194.135 ; P<0.001)$. However, while there were worse results in these years, they were not in chronological order (Figure 3 ).

\subsection{Evaluation of entities based on the Taffler model}

In comparison to the Altman model, we did not see the same skewness with the Taffler model, whether positive or negative. However, in most years, a positive skewness prevailed (with the exception of 2004, 2008, and 2015). This similarly confirmed a large number of subjects with below-average ratings. The Taffler model rated agricultural enterprises more positively, because 8 of the 13 years under review were rated by an index A of T $>0.3$. However, due to the post-2009 results, we consider this assessment to be misleading (the maximum median in later years was $\left(\tilde{x}_{T A F 2011}=0.32\right)$. See Figure 4 for more information.

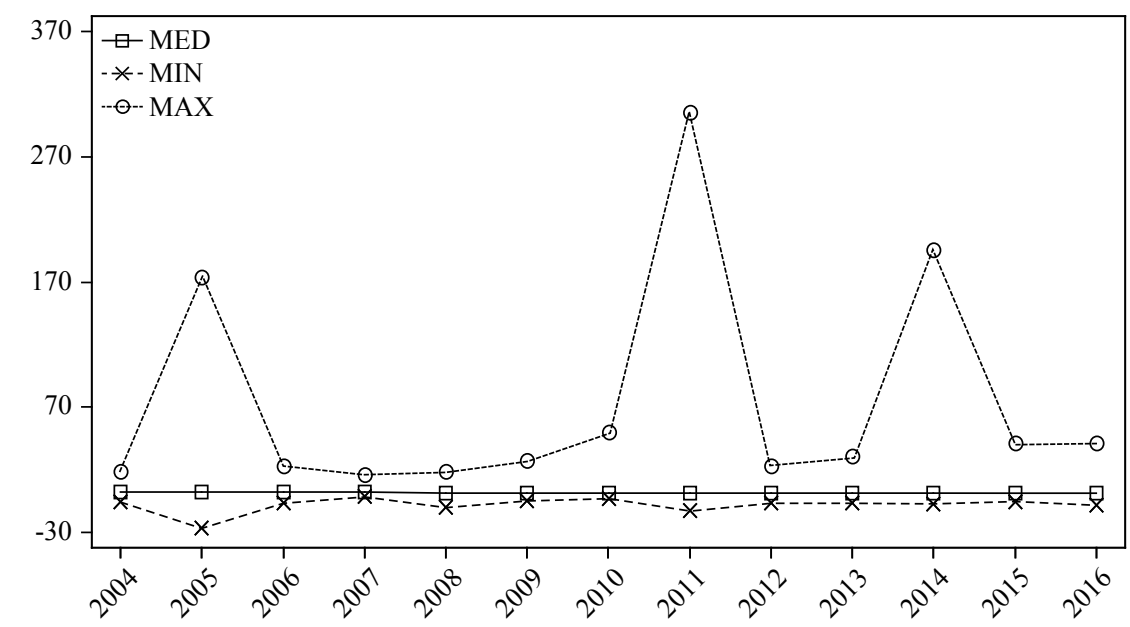

Figure 2. Assessment using the Altman model during 2004-2016. 
A

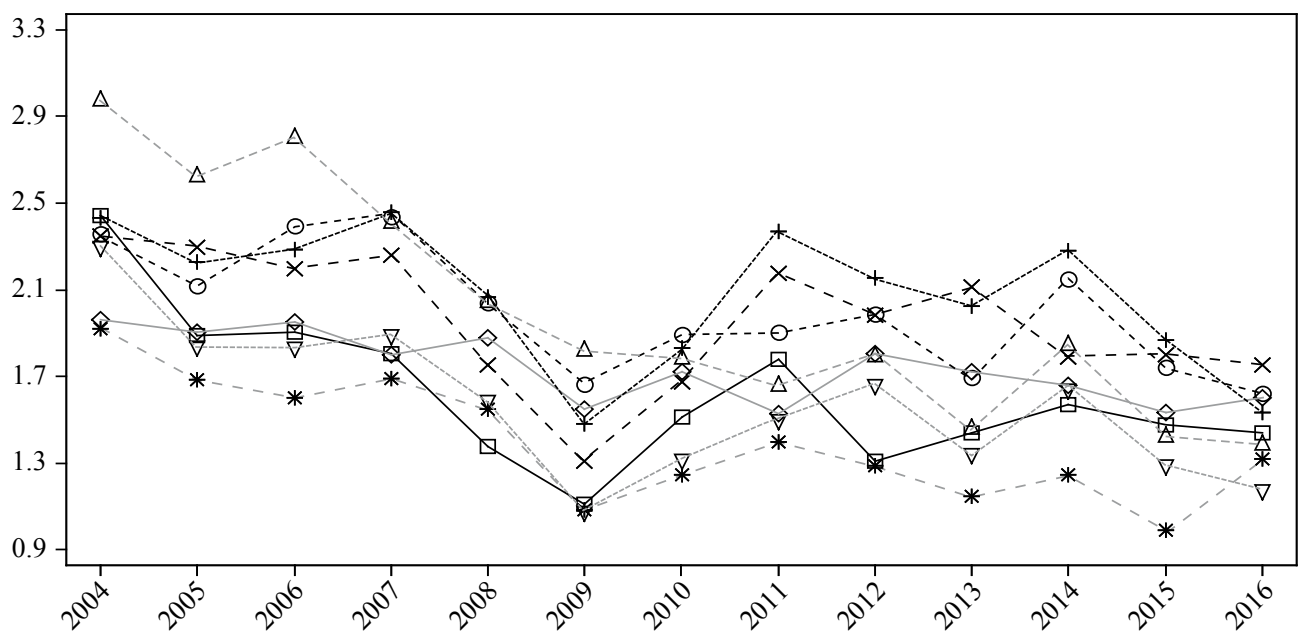

B

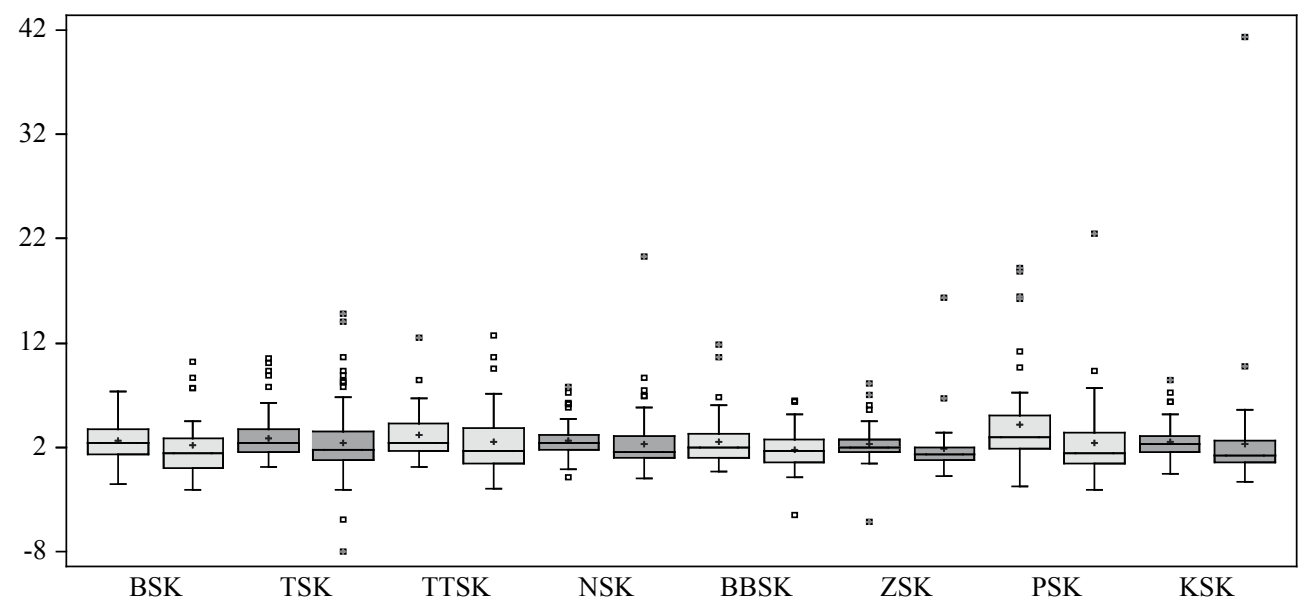

Figure 3. Assessment using the Altman model processed over years 2004-2016 (A) and between regions of the Slovak Republic (B) by legal form. BBSK = Banská Bystrica region; BSK = Bratislava region; KSK = Košice region; NSK $=$ Nitra region; PSK $=$ Prešov region; TSK $=$ Trnava region; TTSK $=$ Trenčín region;

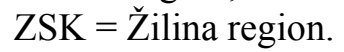

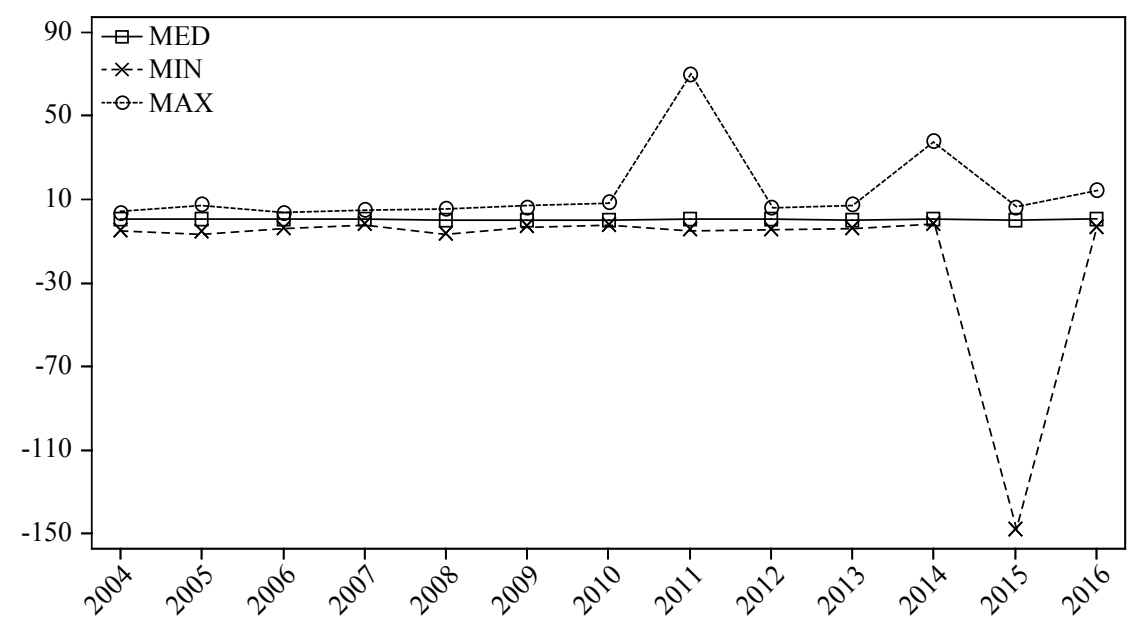

Figure 4. Assessment using the Taffler model during 2004-2016. 
When evaluating the entire 13-year period, it was not possible to confirm a clearly negative or positive trend. When evaluating the worst subjects, we could observe negative values (accompanied by an extreme value in 2015); however, we believe these results are likely attributable to individuals, not groups. This claim was supported by, e.g. the values in the lower quartile or 1/6 sextile, which (with the exception of 2009) were positive, and was also supported by the equal variance in the results in individual years (LE=1.6144; $P=0.0802$ ). The mean values of the annual evaluations of agricultural enterprises were significantly different $(\mathrm{Q}=402.994 ; P<0.01)$, which may have been due to better results overall from the beginning of the reporting period (Figure 5).

A

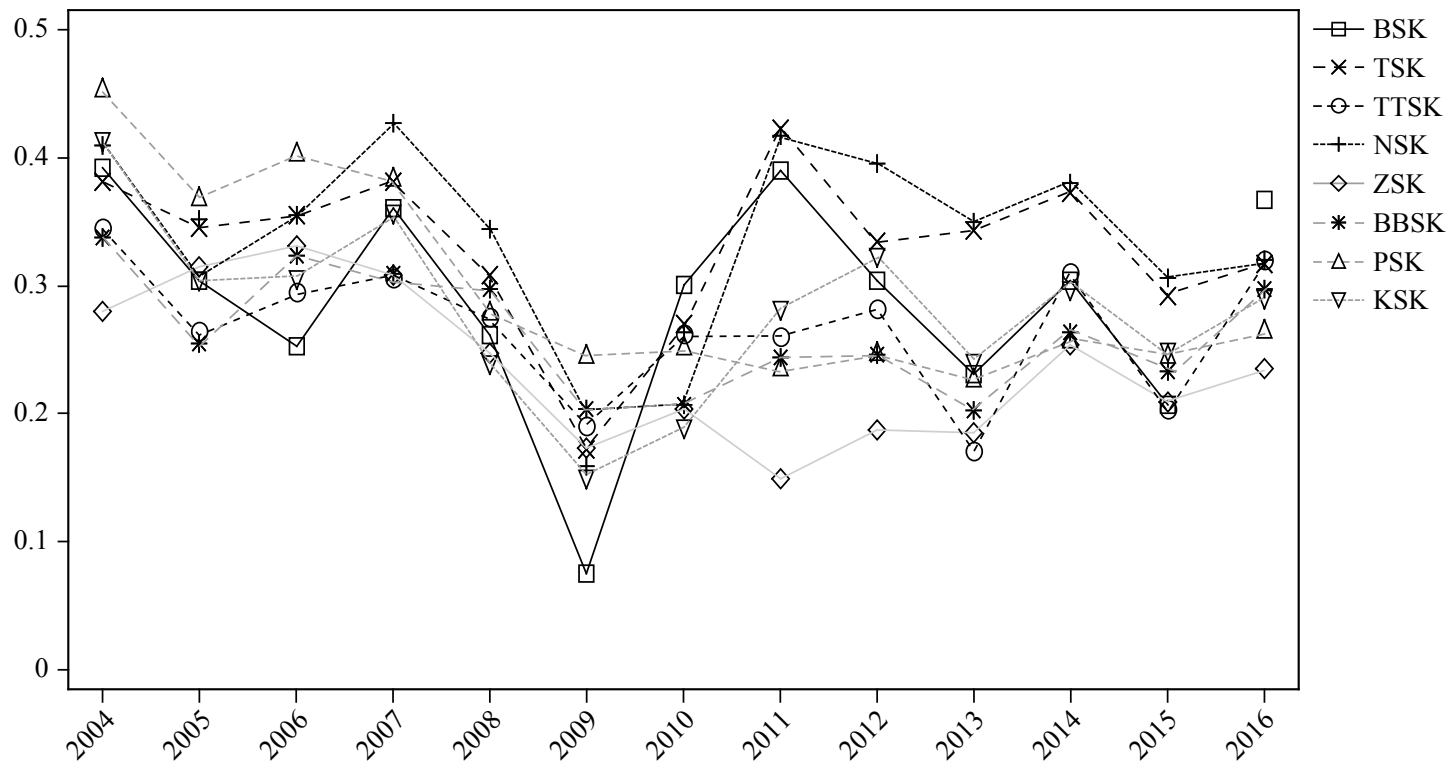

B

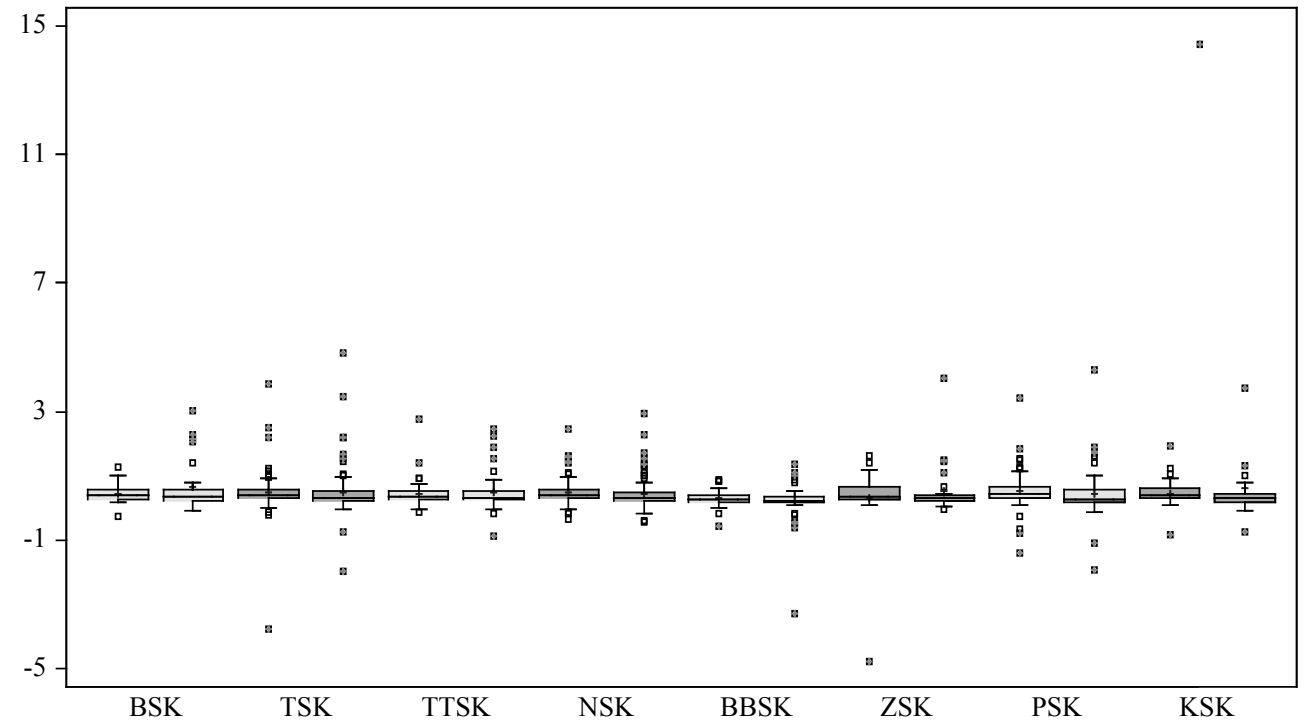

Figure 5. Assessment using the Taffler model over years 2004-2016 (A) and between regions of the Slovak Republic (B) by legal form. BBSK = Banská Bystrica region; BSK = Bratislava region; KSK = Košice region; NSK $=$ Nitra region; $\mathrm{PSK}=$ Prešov region; $\mathrm{TSK}=$ Trnava region; TTSK $=$ Trenčín region; ZSK $=$ Žilina region. 


\subsection{Evaluation of entities based on the Bonity index}

When assessing the agricultural enterprises using the Bonity index, it was not possible to observe a positive skewness in most years, as in the case of the Altman model or the Taffler model. We observed a higher proportion of subjects with worse evaluations, especially in the first years of the monitored period (20052008). At the end of the period, the situation was quite the opposite. Only in 2004 and 2011 did the 5/6 sextile exceed the values required for evaluation by index A. See Figure 6 for more information.

In terms of development, there were fluctuations in both the minimum and maximum values over the 13 years. The average and median values decreased over the years. These differences, in terms of mean value, were significant $(\mathrm{Q}=359.406 ; P<0.01)$, but we observed a maximum of two consecutive periods of decline or growth. The differences between the annual evaluations were also demonstrated in their variance (LE=5.01705; $P<0.01$ ), which could be expected with respect to their moment characteristics, which are shown in Figure 7.

\subsection{Comparison of the results obtained regarding agricultural enterprises}

A comparison of the results obtained using the Altman model, the Taffler model, and the Bonity index was carried out by evaluating the three research hypotheses (Figure 8).

With the first research hypothesis (H1), we assumed that there would be significant differences in the evaluation of agricultural enterprises by individual creditworthy model. Figure 7 points out the fact that, e.g. in 2004, in at least $56 \%$ of cases, changes in the model also resulted in changes in an enterprise's assessment, particularly in terms of classification by index A, B, or C (Table 1). The biggest negative differences (the worst evaluations) were observed with the Altman model, compared to both the Taffler model and the Bonity index. In 2016, we noted that this repeated, but at the same time, there was a reduction in disparity using the last two models (fewer different classifications). The different assessments (indices) over the entire reporting period are shown in Figure 9.

On the basis of the above, we concluded that the differences in the evaluations of agricultural enterprises using individual creditworthy models were significant. Research Hypothesis 1 was confirmed.

With the second hypothesis, we wanted to verify the impact of the legal form of an agricultural enterprise on its evaluation using the individual creditworthy models, i.e. the Altman model, the Taffler model, and the Bonity index (Figure 10). In 2004, we could see the biggest difference between these legal forms in the

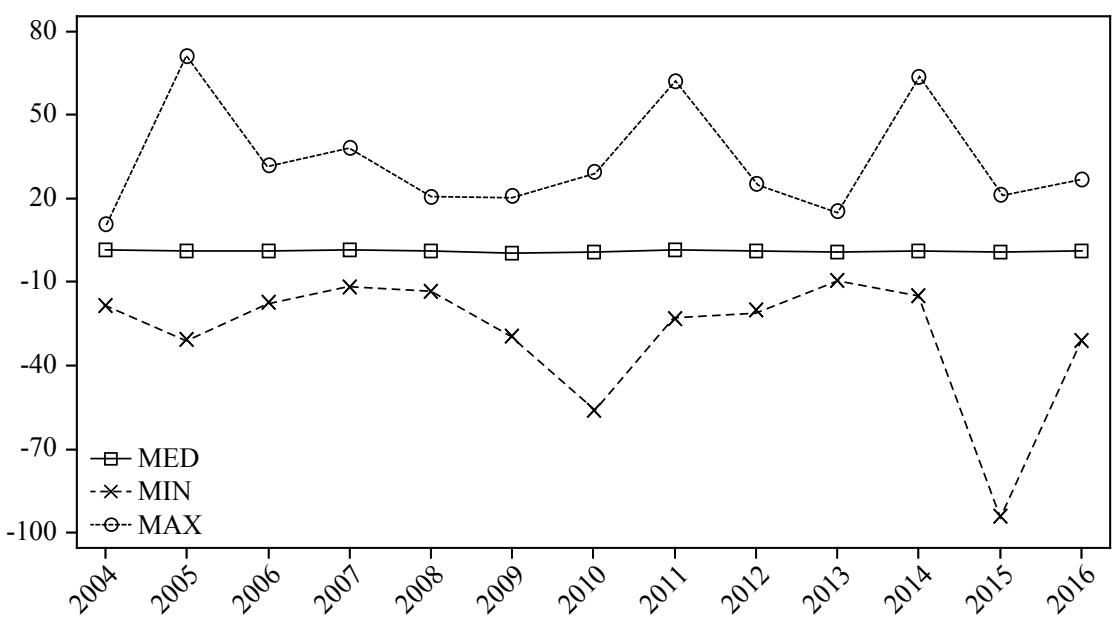

Figure 6. Assessment using the Bonity index during 2004-2016. 
A

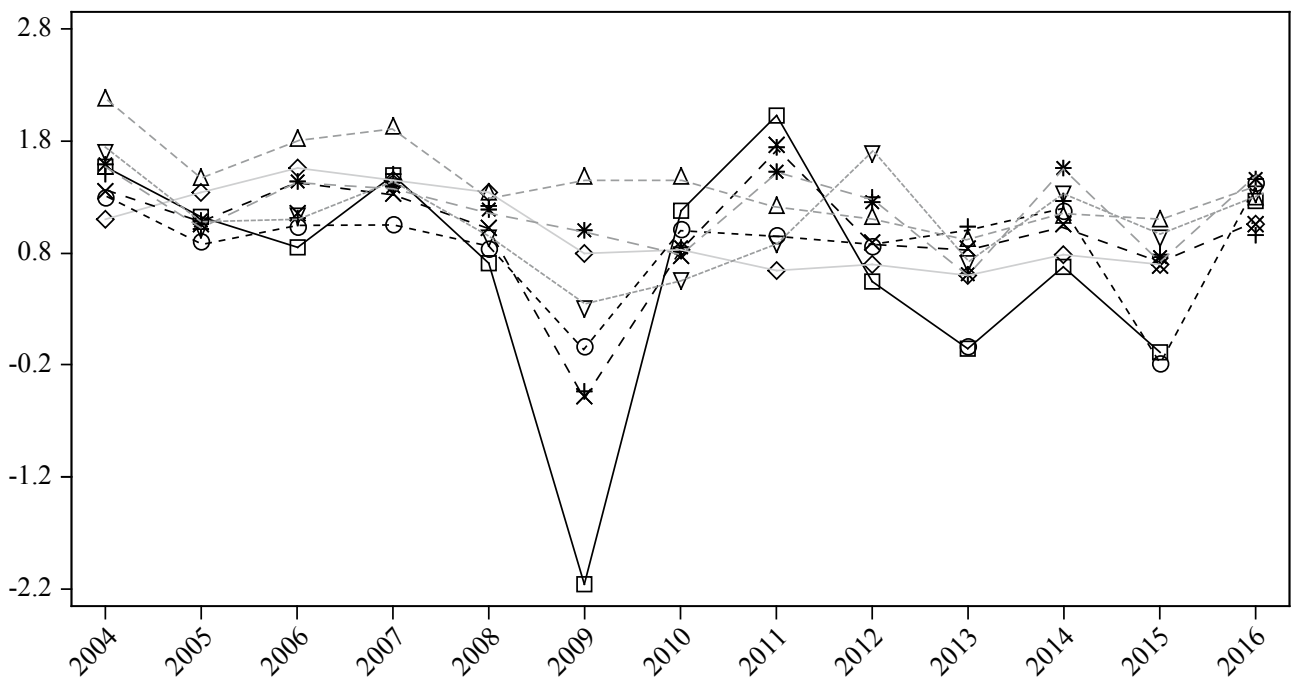

B

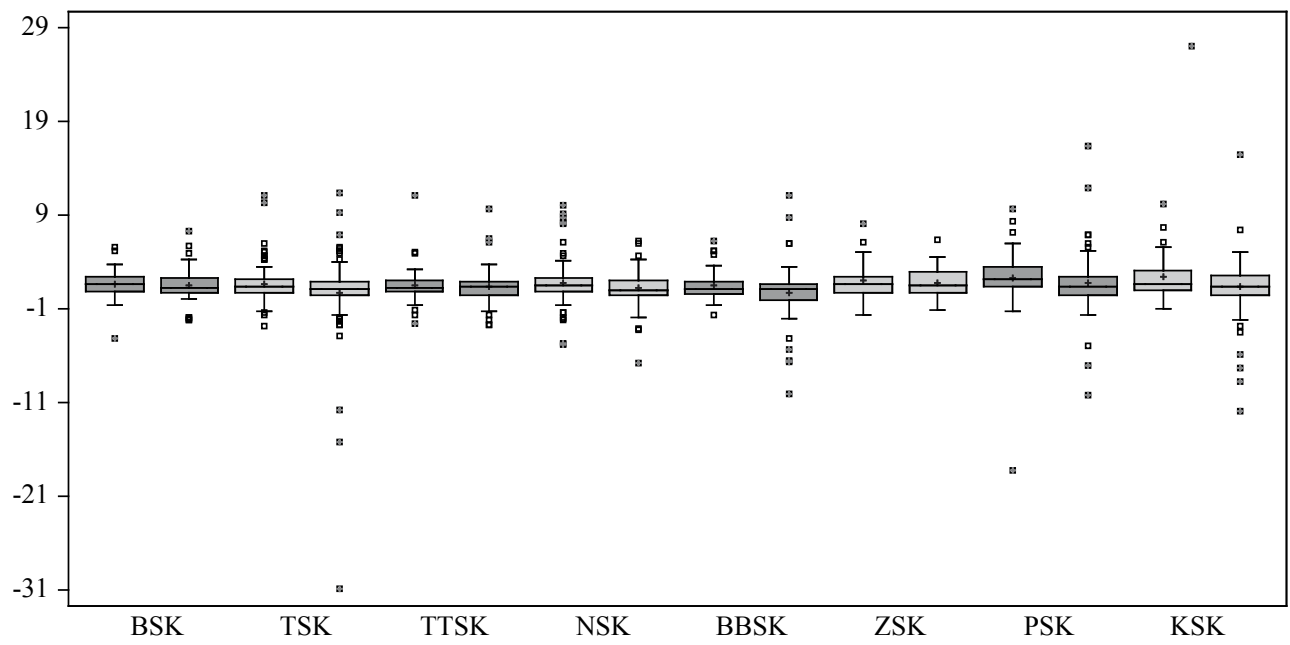

$\square-\mathrm{BSK}$

$-\star-$ TSK

- $\theta-$ TTSK

-- NSK

$\diamond$ ZSK

* - BBSK

$\triangle-$ PSK

$\nabla-\mathrm{KSK}$

Figure 7. Assessment using the Bonity index over years 2004-2016 (A) and between regions of the Slovak Republic (B) by legal form. BBSK = Banská Bystrica region; BSK = Bratislava region; KSK = Košice region; NSK $=$ Nitra region; $\mathrm{PSK}=$ Prešov region; $\mathrm{TSK}=$ Trnava region; $\mathrm{TTSK}=$ Trenčín region; $\mathrm{ZSK}=$ Žilina region.
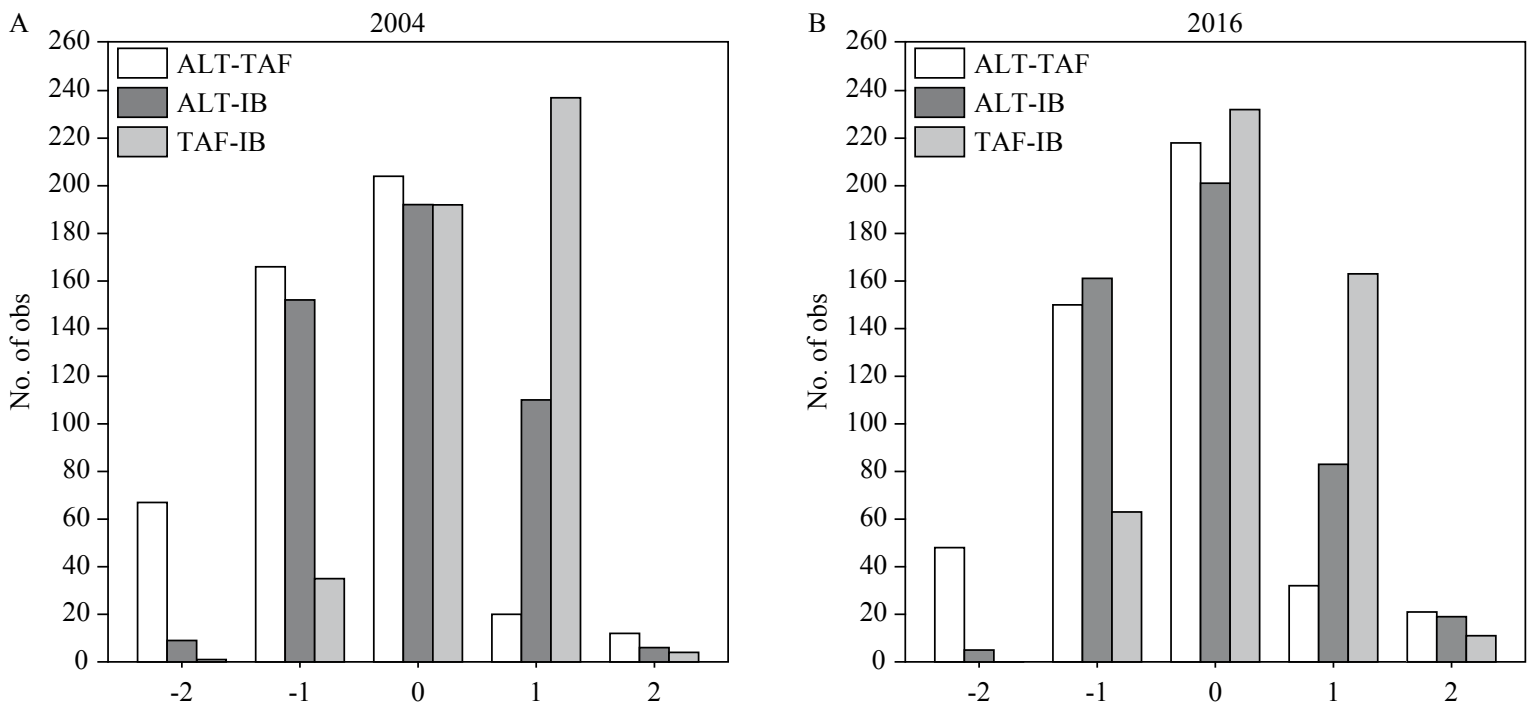

Figure 8. Differences in the assessment (by index) of individual models in 2004 (A) and 2016 (B). ALT = Altman model; IB = Bonity index; TAF = Taffler model. 


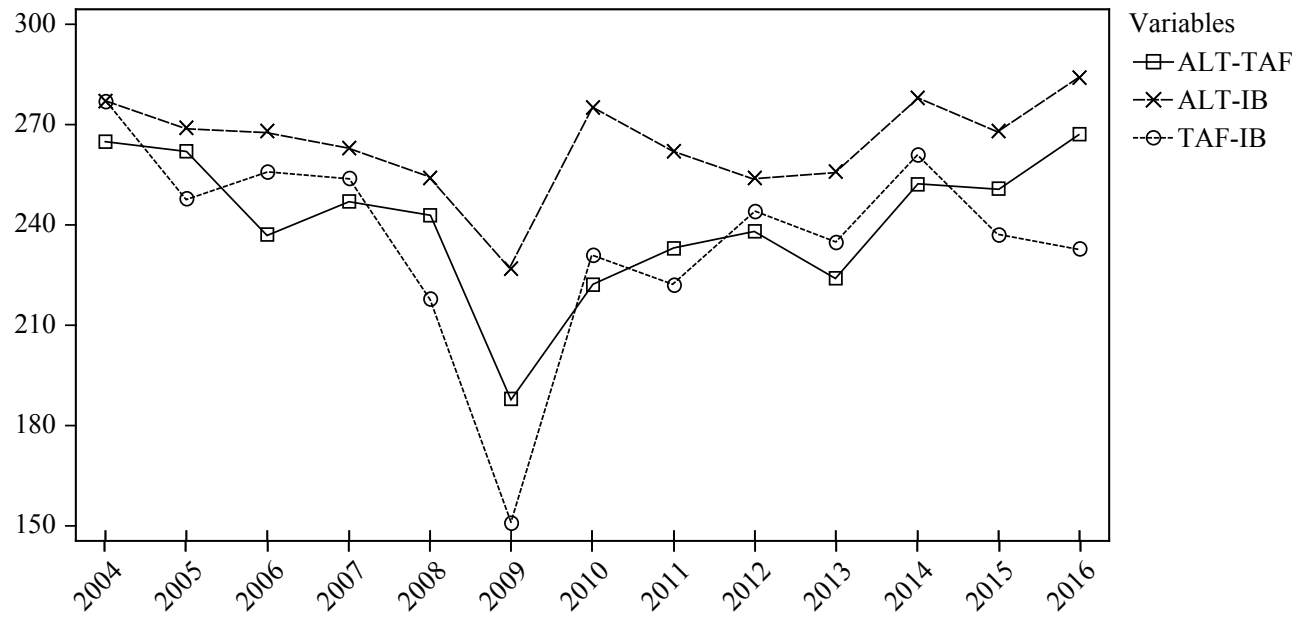

Figure 9. Different assessments (by index) between pairs of creditworthy models over 2004-2016. ALT = Altman model; IB = Bonity index; TAF $=$ Taffler model.

first of these models, the Altman model. This difference was also shown to be statistically significant when comparing the mean value $\left(\mathrm{W}_{\mathrm{ALT}}=18,876 ; P<0.01\right)$ and even the overall structure of the results $\left(\mathrm{KS}_{\mathrm{ALT}}=0.2423\right.$; $P<0.01)$ (although the same variance was maintained $\left(\mathrm{LE}_{\mathrm{ALT}}=1.299 ; P=0.2548\right)$ ). Similar results were observed in 2004 for the other two models, with the Bonity Index results $\left(\mathrm{LE}_{\mathrm{IB}}=27.6503 ; P<0.01\right)$ being heteroskedastic. In 2016, the identified differences persisted only in the Altman model. An analysis of the results of the other two models showed their independence from legal form. Differences across the entire monitored period are shown in Table 4.

In Table 4, we can observe significant differences in the results from the individual models when agricultural entities according to legal form were evaluated. Significant differences were found throughout the reporting period using the Altman model, in which agricultural cooperatives were ranked higher. In the case of the other two models, the identified differences were not long-term: in selected years, companies with alternative legal forms were evaluated as better in comparison to agricultural cooperatives. On the basis of the above, we concluded that the differences in the evaluations of agricultural enterprises by legal form were significant, so research Hypothesis 2 was confirmed. However, when interpreting the results, it is necessary to take into account the model used for the evaluation.
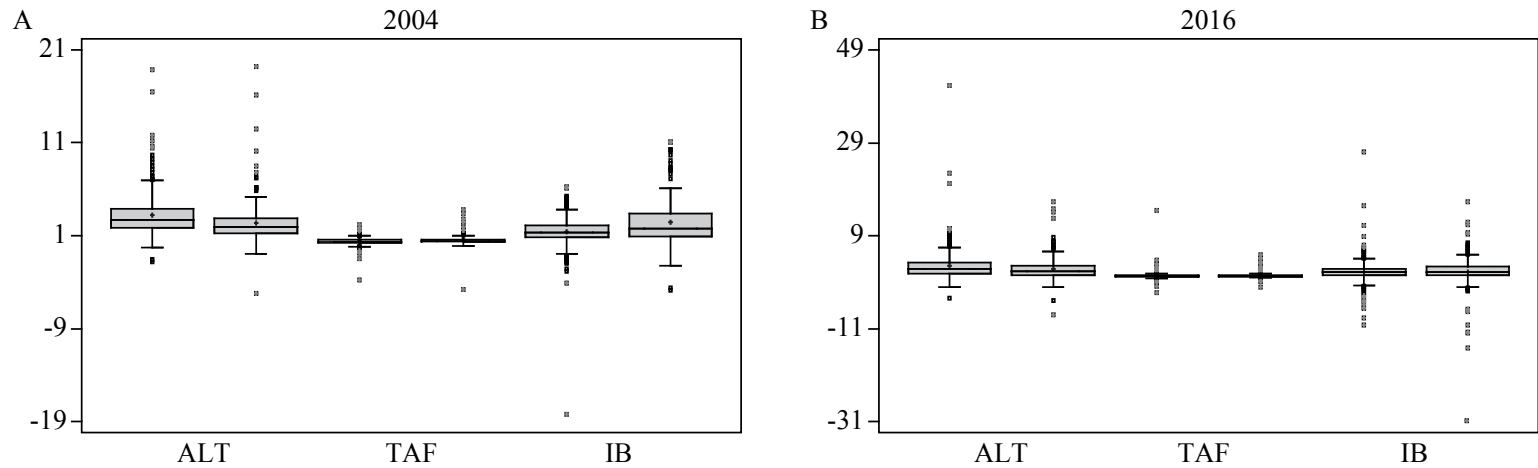

Figure 10. Comparison of results in 2004 (A) and 2016 (B) by legal form. $0=$ agricultural cooperative; $1=$ company with another legal form. ALT $=$ Altman model; $\mathrm{IB}=$ Bonity index; TAF $=$ Taffler model . 
Table 4. Differences in the evaluation of creditworthy models by legal form from 2004 to $2016{ }^{1}$

\begin{tabular}{|c|c|c|c|c|c|c|c|c|c|c|c|c|c|c|}
\hline Model $^{2}$ & & 04 & 05 & 06 & 07 & 08 & 09 & 10 & 11 & 12 & 13 & 14 & 15 & 16 \\
\hline \multirow[t]{3}{*}{ ALT } & W & $*$ & $*$ & $*$ & $*$ & $*$ & $*$ & $*$ & $*$ & $*$ & $*$ & $*$ & $*$ & $*$ \\
\hline & K-S & $*$ & $*$ & $*$ & $*$ & $*$ & $*$ & $*$ & $*$ & $*$ & $*$ & $*$ & $*$ & $*$ \\
\hline & LE & & & $*$ & & $*$ & & & & & & & & \\
\hline \multirow[t]{3}{*}{ TAF } & $\mathrm{W}$ & $*$ & $*$ & $*$ & & & $*$ & $*$ & & & $*$ & & & \\
\hline & K-S & $*$ & $*$ & & & & $*$ & $*$ & & $*$ & $*$ & & $*$ & \\
\hline & $\mathrm{LE}$ & & & & $*$ & & & & & & & & $*$ & \\
\hline \multirow[t]{3}{*}{ IB } & $\mathrm{W}$ & $*$ & $*$ & $*$ & $*$ & & $*$ & $*$ & & $*$ & $*$ & & & \\
\hline & K-S & $*$ & $*$ & & $*$ & & $*$ & $*$ & & $*$ & $*$ & & & \\
\hline & LE & $*$ & & & $*$ & & & & & & & & $*$ & $*$ \\
\hline
\end{tabular}

$1 *$ means significantly different at a significance level of $\alpha=0.05$.

${ }^{2} \mathrm{ALT}=$ Altman model; $\mathrm{IB}=$ Bonity index; $\mathrm{TAF}=$ Taffler model.

For the third hypothesis, we evaluated the spatial relationships between the 469 agricultural subjects using the aforementioned three creditworthy models. Throughout the entire monitoring period, there was high spatial noncorrelation, and the randomness of the results can be seen in Figure 11. The results obtained using both mean values in each year (the median and average) oscillated around zero and did not exceed the value of the Moran index (I) at a level of 0.062 .

On the basis of the above, we concluded that the spatial differences in the evaluations of agricultural enterprises using individual creditworthy models were not statistically significant and were therefore random. Therefore, research Hypothesis 3 was confirmed.

In the $21^{\text {st }}$ century, the assessment of the financial performance of enterprises is a popular issue, studies businesses across sectors, countries and size. The importance of these results is underlined by the fact that information about future financial prosperity eliminates potential financial risk and enables an evaluation of the financial health of a company based on selected financial indicators or other characteristics of the company or environment in which it operates (Valašková et al., 2018). The failure itself can have various forms, performance or results, which all interested groups have to bear with in the market economy whether they are owners, employees, business partners, competitors, state, etc. The failure affects not only company's competitiveness but also its own existence. For this reason, it is very important for the company and other interested groups to identify situations, which able to lead the company to its failure (Zvarikova et al., 2017).
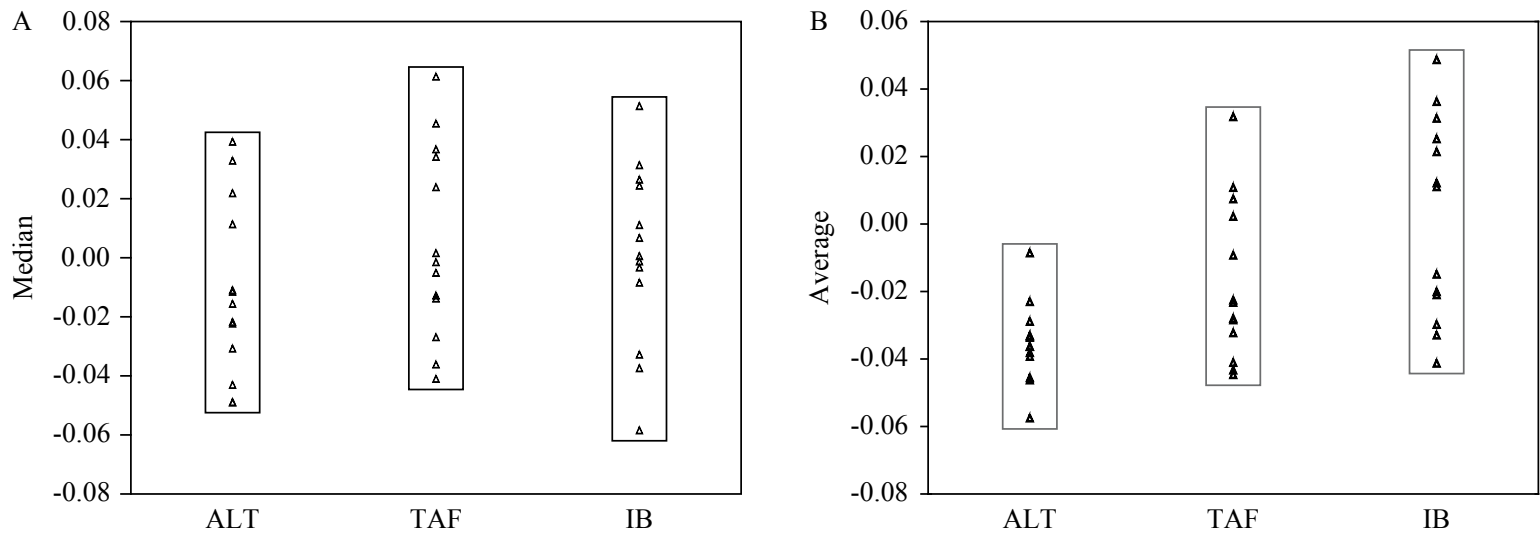

Figure 11. Variability of spatial autocorrelation during the entire monitoring period expressed by median (A) and average (B). $0=$ agricultural cooperative; $1=$ company with another legal form. ALT $=$ Altman model; $\mathrm{IB}=$ Bonity index; TAF $=$ Taffler model . 
According to Alaminos et al. (2016), the recent world financial crisis has increased the number of bankruptcies in numerous countries and has brought on a new area of research, creating the need for models to predict this phenomenon. This need seems to be a consequence of the globalization process, whose impacts are also seen in agribusiness environment. Agribusiness is a process that depends on a lot of internal and external factors that are partly possible and partly impossible to influence. It is important that management is able to channel or use the influence of such factors for successful future development. An analysis of economic effects and processes in an enterprise is important for successful management. Economy of farms is specific and has unique aspects, so it is important to consider this in an analysis (Novotná and Svoboda, 2014). The activities of agricultural entities are affected by state subsidy policy, the high competitiveness of the majority of foreign entities, and support mechanisms under detailed supervision. Important tools for assessing the financial health are creditworthy and bankruptcy models that provide a specialized as well as a comprehensive view of the subject. This study assessed the financial health of 469 agricultural companies in 2016 using three creditworthy models, namely the Altman model, Taffler model, and the Bonity Index. Each has its advantages and disadvantages, thus the individual companies were evaluated by combining all three models.

The financial health of the agricultural companies is an important prerequisite for ensuring the quality of life in the regions, which is related to ensuring the sustainable development while maintaining the competitiveness and optimum performance of the agrarian sector in the European Union single market. For agricultural companies, profitability is always measured in financial terms, as the financial health of agribusinesses affects the economic development of a country; on the contrary, 'nonprofitable' farming production only has a marginal place in an agricultural economy and can be considered to be more in the realm of social policy (Cochet, 2015). The results obtained during the monitored period contributed to deepen the knowledge in the solved issue and enabled to evaluate the financial health of the agricultural enterprises according to the regional differentiation of Slovak Republic as well as according to the legal form with emphasis on the sustainable development. According to Adamišin et al. (2017) the transformation process with its negative consequences (especially for the original cooperatives) was not the key determinant of the persistent differences. From their perspective, the legal form seems to be the key factor, because in the case of businesses, it allows (also by the concentration of ownership of the company) an efficient management, a higher level of the motivation and the concentration of ownership and responsibility. The differences between the management of these legal forms were confirmed also in the study on the basis of the results of one-way analysis of variance and the evaluation of the TOPSIS technique (Kravčáková Vozárová et al., 2016).

In addition to the production factors (labor, capital and natural resources), agricultural companies also need subjective prerequisites to achieve the optimal level of the financial health such as: imagination, ambition, willingness to bear risk, better organizational and management skills, patience and a sense of innovation. This is also described by the study of Henning and Jordaan (2016), who confirmed relationship between the managerial and entrepreneurial characteristics (such as the ability to manage different aspects of the farm business) and the financial health of the enterprise. Our results were also consistent with the findings of Adamišin et al. (2017), whose conclusions were related to economic theory and the phenomenon known as the principal-agent problem. Those who hold these theoretical assumptions are mostly companies with management structures that can effectively solve the problem of how to organize and manage different business processes to save on transaction costs. According to Ali (2018), understanding perceived business obstacles, the characteristics of an enterprise, and business performance from a scale perspective helps agribusiness managers align themselves with the needs of the supply chain and policymakers in order to design better policy support.

Piterková et al. (2014) also devoted to the determinants for classification of prosperous and unprosperous farms. Their study examined the variables with the highest discriminant ability for classification of farms. Among such variables were included the legal form, the share of the animal production and the employees or owners per ha of agricultural land. Melo (2014) evaluated the level at which Slovak regions contributed to the sustainability within the agricultural sector. The results of this study confirmed the regional disparities mostly manifested between the regions of western part of Slovakia and the regions of East or Central part 
of Slovakia. According to this study it was possible to state that these geographical areas were clearly underdeveloped. However, the agrarian traditions of the business environment, which flow from the qualified human resources, adequate natural conditions and high proportion of rural population, with high level of the unemployment in a large part of the Slovakia's regions, as well as other factors, represent an opportunity to revitalize the agricultural business (Šimo et al., 2016).

\section{Conclusion and recommendations}

One current issue is the assessment of the financial health of both public and private sector entities. The activity of agricultural enterprises is very specific, as it is directly dependent on a state's subsidy policy, and agribusinesses face increasingly higher and higher competition, especially from third-country enterprises. Support for agribusiness is accompanied by significant bureaucracy and administration.

There are several ways to evaluate these enterprises. One way is to evaluate financial health using creditworthy models. In the case of the assessment of a homogeneous group of entities (operating under the same conditions, i.e. at the level of the state), evaluations provide a specialized and at the same time comprehensive view that captures several aspects of management. The present research was aimed at assessing the financial health of 469 agricultural enterprises over the period 2004-2016, a 13-year period that we believe was sufficient to produce relevant results. The use of any model of financial analysis is determined by the model itself, its structure of indicators as well as the weights, that are assigned to these indicators. In order to increase the objectivity of the results obtained and to verify the hypothesis were selected three most common (in practice) models used, i.e. the Altman model, the Taffler model and the Bonity index. The results of these models were analyzed separately due to their uniqueness, and we finally synthesized them into an evaluation of three established research hypotheses.

The Altman model, the first of the three creditworthy models used, assessed the agricultural enterprises the most negatively. Every year, we observed that more than $50 \%$ of the evaluated subjects were in the gray zone of evaluation: their evaluations indicated problems for the future. The Taffler model looked somewhat more positively at the financial health of these entities, but we identified positive skewness, and thus a greater number of below-average enterprises persisted. However, the identified differences could not be arranged chronologically, and thus it was not possible to analyze trends across the entire reporting period. With the Bonity index, we observed an increase in the number of above-average enterprises; however, they could not be evaluated positively due to their overall negative financial health.

For the first research question, we identified many differences in the individual creditworthy models when comparing the obtained results. Each of the used creditworthy model categorized its ratings into one of three categories. In 2004, $56 \%$ of the cases were different, which led to the confirmation of the first hypothesis (H1). The second research question involved the impact of the legal form of an agricultural enterprise on its financial health. Significant differences in the results of the two groups were clearly demonstrated in the Altman model. In the other two models, it was also possible to identify differences in the mean value, variance, or distribution function of the results, but these differences were not observed throughout the 13year period. These results led us to confirm the second research hypothesis (H2). The third research question focused on an evaluation of the results in space, and on the basis of the analysis, we could conclude complete independence. The Moran index values were in the range $\mathrm{I} \epsilon<-0.0577 ; 0.0620>$ during the entire period from 2004 to 2016, and thus was confirmed the third hypothesis (H3).

The management of these entities cannot be perceived negatively in the context of the results obtained but on the other hand, it is necessary to pay due attention to this fact as the current situation may not be sustainable in the long term. The results of different businesses can be determined not only by different approaches to the management of entities, but also as a consequence of different starting points in the past. In the view of the absence of the existing studies, further analyses will also focus on measuring the differentiated economic performance of entities according to other criteria in order to more objectively evaluate the results obtained 
(for example, where the ambivalence of agrarian subsidies and subsidy policy is indicated). This study can be useful in helping to design policies that efficiently support agricultural enterprises in Slovakia and can serve as an interesting resource for researchers, bankers, or managers in effectively solving the important challenges faced by agribusiness enterprises in the agribusiness environmental conditions of Slovakia.

The subject of this paper was to evaluate the financial health of 469 agricultural enterprises using three creditworthy models and to interpret the obtained results at the NUTS III level. This research should be viewed in the context of the constraints arising from the design of creditworthy models themselves and the level of spatial units used. In ensuing research, it will also be necessary to consider the use of other models (perhaps ones based less on theory) or to explore spatial connections not from the point of view of administrative regions but rather from the point of view of functional or homogeneous regions.

\section{Acknowledgements}

This research was funded by the Scientific Grant Agency of the Ministry of Education, Science, Research, and Sport of the Slovak Republic and the Slovak Academy of Sciences, grant numbers VEGA 1/0648/21 and VEGA 1/0082/19; and by the Cultural and Educational Grant Agency of the Ministry of Education, Science, Research and Sport of the Slovak Republic, grant number KEGA 024PU-4/2020; and also by the Student Grant Competition in VŠB - Technical University of Ostrava, grant number SP2022/29.

\section{Conflict of interest}

The authors declare no conflicts of interest.

\section{References}

Adamišin, P., R. Kotulič and I. Kravčáková Vozárová. 2017. Legal form of agricultural entities as a factor in ensuring the sustainability of the economic performance of agriculture. Agricultural Economics - Czech 63(2): 80-92. https://doi.org/10.17221/208/2015-AGRICECON

Alaminos, D., A. Del Castillo and M.A. Fernandez. 2016. A global model for bankruptcy prediction. PLoS ONE 11(11): e0166693. https://doi.org/10.1371/journal.pone.0166693

Ali, J. 2018. Performance of small and medium-sized food and agribusiness enterprises: evidence from Indian firms. International Food and Agribusiness Management Review 19(4): 53-63. https://doi. org/10.22434/IFAMR2016.0024

Altman, E.I. 1968. Financial ratios, discriminant analysis and the prediction of corporate bankruptcy. The Journal of Finance 23(4): 589-609. https://doi.org/10.1111/j.1540-6261.1968.tb00843.x

Altman, E.I. 2000. Predicting financial distress of companies: revisiting the z-score and ZETA ${ }^{\circledR}$ models. Available at: http://pages.stern.nyu.edu/ ealtman/Zscores.pdf

Altman, E.I. 2002. Bankruptcy, credit risk and high yield junk bonds. Blackwell Publishers, New York, NY, USA.

Altman, E.I. 2018. Applications of distress prediction models: what have we learned after 50 years from the z-score models? International Journal of Financial Studies 6: 70. https://doi.org/10.3390/ijfs6030070

Altman, E.I., R.G. Haldeman and P. Narayanan. 1977. ZETA analysis. A new model to identify bankruptcy risk of corporations. Journal of Banking and Finance 1(1): 29-54. https://doi.org/10.1016/03784266(77)90017-6

Bellovary, J., D. Giacomino and M. Akers. 2007. A review of bankruptcy prediction studies: 1930-present. Journal of Finance Education 33: 1-42.

Bod'a, M. and V. Úradníček. 2019. Predicting financial distress of Slovak agricultural enterprises. Ekonomický Časopis 67(4): 426-452.

Bondareva, I. 2013. Finančná Analýza v Kontexte Udržatel’ného Rozvoja Podnikatel'ského Subjektu [financial analysis in the context of sustainable business development]. Satis, Bratislava, Slovakia. 
Boratyńska, K. 2016. Corporate bankruptcy and survival on the market: lessons from evolutionary economics. Oeconomica Copernicana 7(1): 107-129. https://doi.org/10.12775/OeC.2016.008

Chrastinová, Z. 1998. Methods of assessment of economic credibility and prediction of financial situation of agricultural companies. Research Institute of Agricultural and Food Economics, Bratislava, Slovakia.

Cochet, D. 2015. Comparative agriculture. Éditions quae, Springer, Versailles, France. https://doi. org/10.1007/978-94-017-9827-0/

Dinterman, R., L. Katchová and J.M. Harris. 2017. Financial stress and farm bankruptcies in US agriculture. Agricultural Finance Review 78(4): 441-456. https://doi.org/10.1108/AFR-05-2017-0030

Dvořák, M. 2007. Analýza finančného zdravia obchodných spoločností podnikajúcich v pol’nohospodárstve [Analysis of the financial health of companies doing business in agriculture]. In: Zbornik $z$ Medzinárodnej Vedeckej Konferencie. Obchod, Jakost a Finance v Podnicích - Determinanty Konkurenceschopnosti V, ČZU v Prahe, Praha, Czech Republic.

Gavurová, B., F. Janke, M. Packová and M. Prídavok. 2017. Analysis of impact of using the trend variables on bankruptcy prediction models performance. Ekonomický Časopis 65(4): 370-383.

Gurčík, L. 2002. Business economy. Slovak University of Agriculture, Nitra, Slovakia.

Gurčík, L., V. Porhajas and K. Gurčíková. 2015. Indebtedness and prosperity determinants of agricultural companies in Slovakia. In: Proceedings of the $9^{\text {th }}$ International Conference on Applied Business Research (ICABR). 26-29 June 2015. Talca, Chile.

Harumová, A. and M. Janisová. 2014. Rating Slovak enterprises by scoring functions. Ekonomický Časopis 62 (5): $522-539$.

Henning, J.I.F. and H. Jordaan. 2016. Determinants of financial sustainability for farm credit applications - a delphi study. Sustainability 8(1): 77. https://doi.org/10.3390/su8010077

Herdt, R.W. and J.K. Lynam. 1992. Sustainable development and the changing needs of international agricultural research. In: D.R. Lee, S. Kearl and N. Uphoff (eds.) Assessing the importance of international agricultural research for sustainable development. Cornell University Press, Ithaca, NY, USA.

Kabát, L., M. Sobeková Majková and Z. Vincúrová. 2013. Hodnotenie Podniku a Analýza Jeho Finančného Zdravia [Evaluation of the company and analysis of its financial health]. Iura Edition, Bratislava, Slovakia.

Karas, M. and M. Rezňáková. 2014. A parametric or nonparametric approach for creating a new bankruptcy prediction model: the evidence from the Czech Republic. International Journal of Mathematical Models and Methods in Applied Sciences 8(1): 214-223.

Karas, M., M. Rezńáková and P. Pokorný. 2017. Predicting bankrutpcy of agriculture companies: validating selected models. Polish Journal of Management Studies 15(1): 110-120. https://doi.org/10.17512/ pjms.2017.15.1.11

Király, P., R. Kotulič, R. and M. Smolko. 2015. SOFINA_Standard (ver. 3.01) - Hospodársky Softvér pre Finančné Plánovanie a Manažérsku Ekonomiku [SOFINA_Standard (ver. 3.01)-economic software for financial planning and managerial economics]. Wolters Kluwer, Bratislava, Slovakia.

Klepáč, V. and D. Hampel. 2017. Predicting financial distress of agriculture companies in EU. Agricultural Economics - Czech 63(8): 347-355. https://doi.org/10.17221/374/2015-AGRICECON

Kopta, D. 2009. Possibilities of financial health indicators used for prediction of future development of agricultural enterprises. Agricultural Economics-Zemedelska Ekonomika 55(3): 111-125. https:// doi.org/10.17221/589-AGRICECON

Kravčáková Vozárová, I., R. Kotulič and R. Vavrek 2016. Legal form as a determinant of the evaluation of agricultural entities in Slovakia using the topsis method. Journal of Environmental Management and Tourism 7(2): 347-354. https://doi.org/10.14505/jemt.v7.2(14).20

Lopez-Valeiras, E., J. Gomez-Conde and T. Fernandez-Rodriguez. 2016. Firm size and financial performance: intermediate effects of indebtedness. Agribusiness 32(4): 454-465. https://doi.org/10.1002/agr.21458

Maciková, L., M. Smorada, P. Dorčák, B. Beug and P. Markovič. 2018. Financial aspects of sustainability: an evidence from Slovak companies. Sustainability 10(7): 2274. https://doi.org/10.3390/su10072274

Majewski, E. 2013. Measuring and modelling farm level sustainability. Visegrad Journal on Bioeconomy and Sustainable Development 2(1): 2-10. https://doi.org/10.2478/vjbsd-2013-0001 
Mandru, L. 2010. The diagnosis of bankruptcy risk using score function. In: L.A. Zadeh, J. Kacprzyk, N. Mastorakis, A. Kuri-Morales, P. Borne and L. Kazovsky (eds.) Proceedings of the $9^{\text {th }}$ WSEAS International Conference on Artificial Intelligence, Knowledge Engineering and Database. 20-22 February 2010. Cambridge, UK.

Martínez-Victoria, M., N.A. Lario and M.M.S. Val. 2018. Financial behavior of cooperatives and investorowned firms: an empirical analysis of the Spanish fruit and vegetable sector. Agribusiness 34(2): 456-471. https://doi.org/10.1002/agr.21513

Mateos-Ronco, A. and S. Guzman-Asuncion. 2018. Determinants of financing decisions and management implications: evidence from Spanish agricultural cooperatives. International Food and Agribusiness Management Review 21(6): 701-721. https://doi.org/10.22434/IFAMR2016.0178

Melo, D. 2014. Evaluation and comparison of the level of regional development and regional disparities in agricultural sector within Slovak regions. In: International Scientific Days 2014 (improving performance of agriculture and the economy, challenges for management and policy): Conference proceedings of reviewed articles. 6 May 2014. Nitra, Slovak Republic.

Novotná, M. and J. Svoboda. 2014. The economic results of farms in the Czech Republic. Journal of Central European Agriculture 15(4): 31-50. https://doi.org/10.5513/JCEA01/15.4.1505

Nývltová, K. 2016. Risk areas of the financial health assessment in agriculture. In: Proceedings of the 25th International Scientific Conference on Agrarian Perspectives - Global and European Challenges for Food Production, Agribusiness and the Rural Economy. 14-16 September 2016. Prague, Czech Republic.

Oreský, M. 2017. Finančná a Ekonomická Analýza Obchodného Podniku [Financial and economic analysis of a business company]. Wolters Kluwer, Bratislava, Slovakia.

Ozalp, A. 2019. Financial analysis of agricultural development cooperatives: a case of western Mediterranean region, Turkey. New Medit 18(2): 119-132. https://doi.org/10.30682/nm1902h

Piterková, A., M. Tóth and P. Serenčéš. 2014. The impact of non-financial factors on prosperity of Slovak agriculture sector. In: Proceedings of the $9^{\text {th }}$ International Conference on Applied Business Research (ICABR 2014). 6-10 October 2014. Talca, Chile.

Pokharel, K.P., M. Regmi, A.M. Featherstone and D.W. Archer. 2019. Examining the financial performance of agricultural cooperatives in the USA. Agricultural Finance Review 79(2): 271-282. https://doi. org/10.1108/AFR-11-2017-0103

Prusak, B. 2018. Review of research into enterprise bankruptcy prediction in selected central and eastern European countries. International Journal of Financial Studies 6(3): 60. https://doi.org/10.3390/ ijfs6030060

Rábek, T. and M. Tóth. 2013. Development of profitability in Slovak agricultural enterprises in years 20042011. European Policies, Finance and Marketing 10(59): 580-587.

Richard, P.J., T.M. Devinney, G.S. Yip and G. Johnson. 2009. Measuring organizational performance: towards methodological best practice. Journal of Management 35(3): 718-804. https://doi. org/10.1177/0149206308330560

Rybárová, D., M. Braunová and L. Jantošová. 2016. Analysis of the construction industry in the Slovak Republic by bankruptcy model. Procedia - Social and Behavioral Sciences 230: 298-306. https:// doi.org/10.1016/j.sbspro.2016.09.038

Sapozhnikova, N.G., Y.A. Batishcheva, T.N. Steklova, I.A. Demchenk and A.Y. Kalnaya. 2017. Improvement of assessment mechanism of agricultural enterprises creditworthiness in conditions of national specificity. Journal of Advanced Research in Law and Economics 24(8): 581-590.

Shadbolt, N.M., D.M. Stuart and C.K. Terry. 1997. Financial indicators of the sustainability of pastoral farms and their relationship with environmental sustainability. Proceedings of the New Zealand Grassland Association 59: 199-204.

Šimo, D., L. Mura and J. Buleca. 2016. Assessment of milk production competitiveness of the Slovak Republic within the EU-27 countries. Agricultural Economics - Czech 62(10): 482-492. https://doi. org/10.17221/270/2015-AGRICECON 
Sjauw-Koen-Fa, A.R., V. Blok and S.W.F. Omta. 2016. Critical success factors for smallholder inclusion in high value-adding supply chains by food \& agribusiness multinational enterprises. International Food and Agribusiness Management Review 19(1): 83-111.

Valášková, K., L. Švábová and M. Ďurica. 2017. Verification of prediction models in conditions of the Slovak agricultural resort. Economics, Management, Innovation 9(3): 30-38.

Valášková, K., T. Klieštik, L. Švábová and P. Adamko. 2018. Financial risk measurement and prediction modelling for sustainable development of business entities using regression analysis. Sustainability 10(7): 2144. https://doi.org/10.3390/su10072144

Vavrek, R., P. Gundová, I. Kravčáková Vozárová and R. Kotulič. 2021a. Altman model verification using a multi-criteria approach for Slovakian agricultural enterprises. Economics and Management 24(1): 146-164. https://doi.org/10.15240/tu1/001/2021-1-010

Vavrek, R., I. Kravčáková Vozárová and R. Kotulič. 2021b. Evaluating the financial health of agricultural enterprises in the conditions of the Slovak Republic using bankruptcy models. Agriculture 11: 242. https://doi.org/10.3390/agriculture11030242

Yaremko, Y., L. Shykova and L. Syvolap. 2018. Methods of evaluation and conceptual-strategic directions of economic security of agricultural enterprises. Baltic Journal of Economic Studies 4(5): 421-430. https://doi.org/10.30525/2256-0742/2018-4-5-421-430

Zhminko, N.S. and A.Y. Zhminko. 2014. The method of financial analysis of agricultural organizations in the Krasnodar region. Economy of Region 1(2): 161-170.

Zorn, A., M. Esteves, I. Baur and M. Lips. 2018. Financial ratios as indicators of economic sustainability: a quantitative analysis for Swiss dairy firms. Sustainability 10(8): 2942. https://doi.org/10.3390/ su10082942

Zvarikova, K., E. Spuchlakova and G. Sopkova. 2017. International comparison of the relevant variables in the chosen bankruptcy models used in the risk management. Oeconomica Copernicana 8(1): 145157. https://doi.org/10.24136/oc.v8i1.10 